\title{
Arrangement and regulation of the genes for meta-pathway enzymes required for degradation of phenol in Comamonas testosteroni TA441
}

\author{
Hiroyuki Arai,† Tohru Ohishi, Mee Young Chang and Toshiaki Kudo
}

Author for correspondence: Toshiaki Kudo. Tel: +8148467 9544. Fax: +81484624672. e-mail: tkudo@postman.riken.go.jp

Laboratory of Microbiology, The Institute of Physical and Chemical Research (RIKEN), Hirosawa 2-1, Wako, Saitama 351-0198, Japan

\begin{abstract}
Comamonas testosteroni TA441 degrades phenol by a meta-cleavage pathway after the occurrence of a spontaneous mutation that derepresses the aphKLMNOPQB operon encoding phenol hydroxylase and catechol 2,3dioxygenase, the enzymes for the initial two steps of the degradation pathway. A gene cluster, aphCEFGHJ, encoding the meta-pathway enzymes for degradation of 2-hydroxymuconic semialdehyde (HMS) to TCA cycle intermediates was found downstream of the aphK operon. The upstream operon and the downstream gene cluster were found to be separated by two open reading frames of unknown function and an oppositely oriented aphT gene, which is similar to regulatory genes for ortho-cleavage of catechol or chlorinated catechols. A promoter assay using an aphC: lacZ transcriptional fusion plasmid revealed that the aphC promoter activity is induced by both phenol and HMS. The phenol-dependent induction was mediated by AphR and the HMS-dependent induction was mediated by AphT. The aphC promoter in strain TA441 was not silenced, unlike the cases of the aphK and aphR promoters, and was highly induced by HMS.
\end{abstract}

Keywords: phenol, meta-pathway, biodegradation, Comamonas testosteroni

\section{INTRODUCTION}

Comamonas testosteroni TA441 does not grow on phenol as a sole carbon source, but it becomes able to utilize phenol after incubation with phenol for a few weeks in liquid medium or for several days on agar plates (Arai et al., 1998, 1999a). Strain TA441 has an operon (aphKLMNOPQB) which encodes phenol hydroxylase $(\mathrm{PH})$ and catechol 2,3-dioxygenase (C23O), the enzymes for the initial two steps of the phenol-

\footnotetext{
† Present address: Department of Biotechnology, University of Tokyo, Yayoi 1-1-1, Bunkyo-ku, Tokyo 113-8657, Japan.

Abbreviations: 3HPP, 3-(3-hydroxyphenyl)propionate; 4OD, 4-oxalocrotonate decarboxylase; 4OI, 4-oxalocrotonate isomerase; ADA, acetaldehyde dehydrogenase (acylating); $\mathrm{C} 230$, catechol 2,3-dioxygenase; CFE, cell-free extract; HMS, 2-hydroxymuconic semialdehyde; HMSD, HMS dehydrogenase; HMSH, HMS hydrolase; HOA, 4-hydroxy-2-oxovalerate aldolase; OEH, 2-oxopent-4-dienoate hydratase; pHB, $p$-hydroxybenzoate; $\mathrm{PH}$, phenol hydroxylase.

The DDBJ/EMBL/GenBank accession number for the sequence reported in this paper is $A B 029044$.
}

degradation pathway via meta-fission, i.e. conversion of phenol to 2-hydroxymuconic semialdehyde (HMS) (Fig. 1 ). The gene for a putative phenol-sensing activator, $a p h R$, is located near $a p h K$, in the opposite orientation. However, the genes are silent until adaptation occurs (Arai et al., 1998). This adaptation occurs through a mutation in the aphS gene, which is located downstream of $a p h R$ and which encodes a protein of the GntR family of transcriptional regulators. The $a p h S$ product binds to the intervening promoter region between $a p h K$ and $a p h R$, and represses the expression of the $a p h K$ and aphR promoters (Arai et al., 1999a).

In Pseudomonas sp. strain CF600, a well-characterized phenol-degrading bacterium, the genes for $\mathrm{PH}$ and $\mathrm{C} 23 \mathrm{O}$ are accompanied by those for the other metapathway enzymes, i.e. HMS dehydrogenase (HMSD), HMS hydrolase (HMSH), 2-oxopent-4-dienoate hydratase $(\mathrm{OEH})$, acetaldehyde dehydrogenase (acylating) (ADA), 4-hydroxy-2-oxovalerate aldolase (HOA), 4oxalocrotonate decarboxylase (4OD) and 4-oxalocrotonate isomerase (4OI) (Fig. 2) (Shingler et al., 1992). 


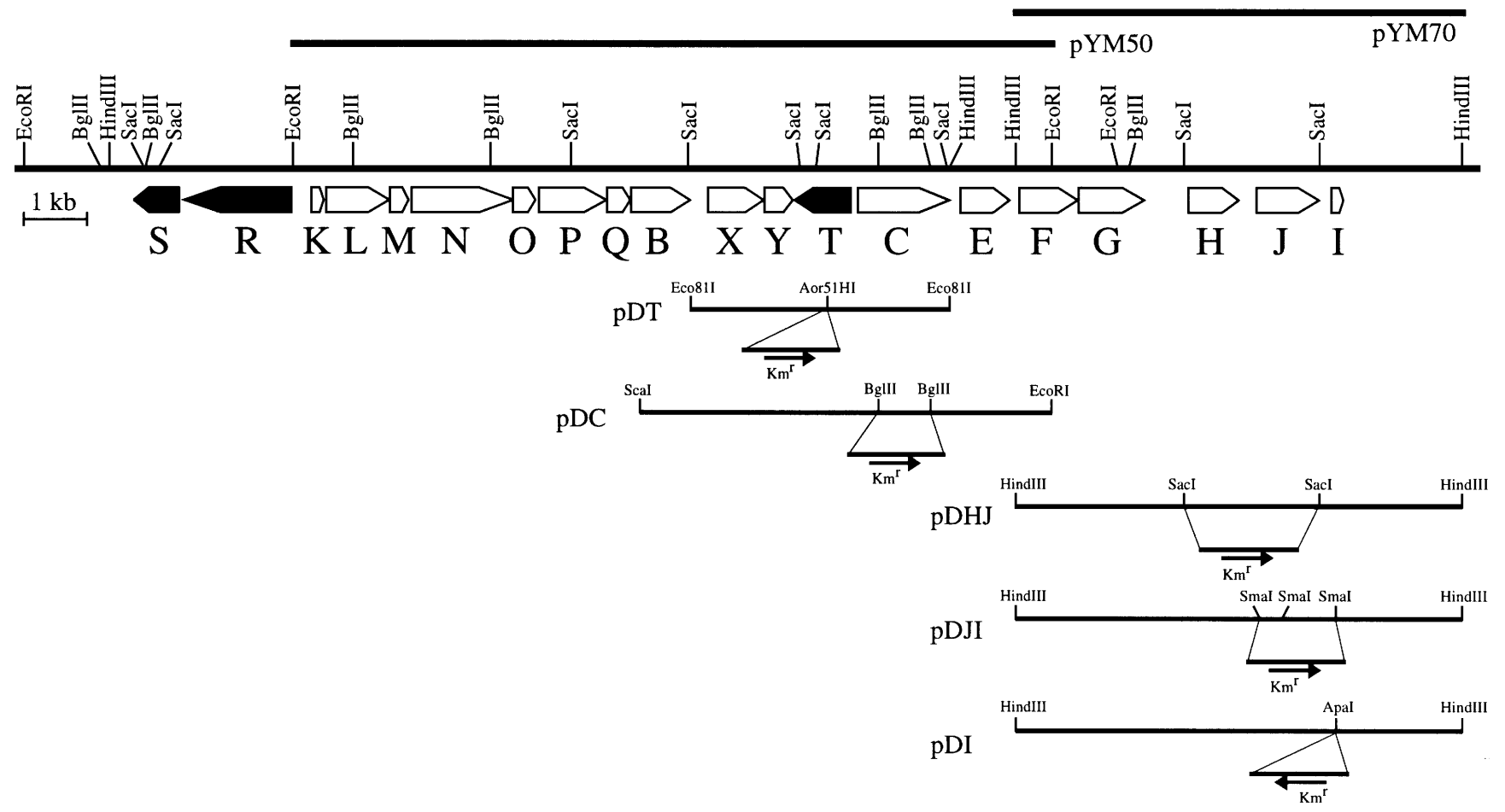

Fig. 1. Physical map of the aph gene cluster from C. testosteroni TA441. Boxes indicate the size and direction of transcription of the aph genes. Black boxes indicate regulatory genes. Upper bars labelled pYM50 and pYM70 indicate the fragments of chromosomal DNA of strain TA441 cloned. Lower bars indicate pUC19-derived plasmids used for construction of mutant strains by homologous recombination.

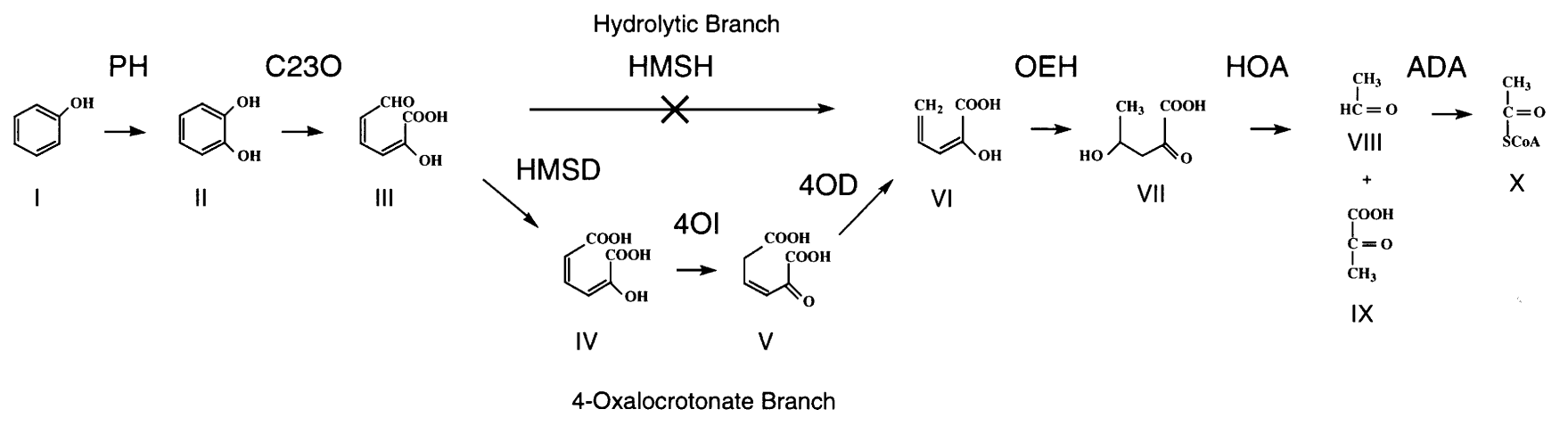

Fig. 2. Phenol catabolic pathway in the adapted strains of $C$. testosteroni TA441. The metabolites are phenol (I), catechol (II), HMS (III), the enol form of 4-oxalocrotonate (IV), the keto form of 4-oxalocrotonate (V), 2-oxopent-4-dienoate (VI), 4hydroxy-2-oxovalerate (VII), acetaldehyde (VIII), pyruvate (IX), acetyl CoA (X). Strain TA441 does not have the hydrolytic branch enzyme HMSH.

There are two routes for conversion of HMS to 2oxopent-4-dienoate; one is the hydrolytic branch catalysed by HMSH and the other is the 4-oxalocrotonate branch catalysed by HMSD, 4OD and 4OI. The hydrolytic branch is required for degradation of 2- or 3 -methylphenol and the 4-oxalocrotonate branch is required for degradation of phenol and 4-methylphenol. Because strain CF600 has both these branches, it can grow on methyl- and dimethylphenols. The genes for all meta-pathway enzymes of strain CF600 are transcribed as an extraordinarily large operon (Shingler, 1996). In this work, we show that the genes for the remaining steps of the complete phenol degradation pathway are clustered in a region downstream of the $a p h K$ operon in strain TA441. However, unlike the case of strain CF600, strain TA441 does not have HMSH and transcription of the downstream genes occurs in a manner independent of the upstream operon. 


\section{METHODS}

Bacterial strains, plasmids and growth conditions. The bacterial strains and plasmids used in this study are listed in Table 1. C. testosteroni strains were cultivated in LB medium or $\mathrm{C}$ medium at $30^{\circ} \mathrm{C}$. C medium was supplemented with phenol, $p$-hydroxybenzoate (pHB), succinate or HMS. HMS was prepared enzymically from catechol using Escherichia coli JM109 cells harbouring pUC18- $x y l E$; the $x y l E$ gene in this plasmid encodes $\mathrm{C} 23 \mathrm{O}$ and is derived from the TOL plasmid (Arai et al., 1999b). Growth was monitored by measuring the $\mathrm{OD}_{550}$. E. coli JM109 was cultivated at $37^{\circ} \mathrm{C}$. The medium composition and concentration of antibiotics have been described previously (Arai et al., 1998).

Recombinant DNA techniques. DNA manipulations were performed by standard methods (Sambrook et al., 1989) or as described previously (Arai et al., 1998). An ABI 373A DNA sequencer (Applied Biosystems) was used for sequence determination. A dye primer cycle sequence kit or a dye terminator cycle sequence kit (Perkin-Elmer) was used for dideoxy chain-termination reactions.

Cloning of the region downstream of the aph gene cluster. Because pYM50 did not contain the complete aph gene cluster, a $7 \mathrm{~kb}$ HindIII fragment (pYM70) containing the downstream region was cloned from total DNA of strain TA441 using a digoxigenin-labelled $0.6 \mathrm{~kb}$ HindIII-EcoRI fragment of pYM50 as a probe (Fig. 1).
Construction of mutant strains. The mutant strains PDT, PDC, PDI, PDJI and PDHJ were constructed by insertion of a kanamycin-resistance $\left(\mathrm{Km}^{\mathrm{r}}\right)$ gene into the chromosome of strain P1 according to the method described previously (Arai et al., 1998) using pDT1, pDC1, pDI1, pDI2 and pDH1, respectively (Fig. 1). Strain TDT was constructed from strain TA441 using pDT1. The plasmids were constructed by subcloning of the indicated fragment into pUC19 and insertion of a blunt-ended $1.5 \mathrm{~kb}$ HindIII-SalI fragment of pSUP5011 which contained the $\mathrm{Km}^{\mathrm{r}}$ gene (Simon, 1984) (Fig. 1). Insertion of the $\mathrm{Km}^{\mathrm{r}}$ gene into the chromosome of the mutant strains was confirmed by PCR (data not shown).

Preparation of cell-free extracts. For preparation of cell-free extract (CFE), strains P1 and PDT were cultivated overnight. The cells were harvested by centrifugation, washed with $50 \mathrm{mM}$ potassium phosphate buffer $(\mathrm{pH} \mathrm{7 \cdot 5)}$, resuspended in the same buffer and disrupted by sonication. The cell debris was removed by centrifugation and the supernatant was used as CFE. Protein concentration was determined by the method of Bradford (1976) using the Bio-Rad protein assay kit, with bovine serum albumin as a standard.

Enzyme assays. All enzyme assays were performed at $30^{\circ} \mathrm{C}$. HMSD and HMSH activities were determined by measuring the decrease in HMS. HMS was prepared from catechol using E. coli JM109 (pUC18-xylE) cells in $50 \mathrm{mM}$ potassium phosphate buffer ( $\mathrm{pH} 7 \cdot 5)$. After the ring-fission reaction was

Table 1. Bacterial strains and plasmids

$\mathrm{Ap}^{\mathrm{r}}$, ampicillin resistance; $\mathrm{Km}^{\mathrm{r}}$, kanamycin resistance; $\mathrm{Tc}^{\mathrm{r}}$, tetracycline resistance.

\begin{tabular}{|c|c|c|}
\hline $\begin{array}{l}\text { Strain or } \\
\text { plasmid }\end{array}$ & Relevant characteristics & Source/reference \\
\hline \multicolumn{3}{|c|}{ C. testosteroni strains } \\
\hline TA441 & Wild-type (JCM9806) & Arai et al. (1998) \\
\hline P1 & Phenol-utilizing mutant of TA441 & Arai et al. (1998) \\
\hline PR921 & aphR mutant of $\mathrm{P} 1 ; \mathrm{Km}^{\mathrm{r}}$ & Arai et al. (1998) \\
\hline TDT & aphT mutant of TA441; $\mathrm{Km}^{\mathrm{r}}$ & This work \\
\hline PDT & aphT mutant of $\mathrm{P} 1 ; \mathrm{Km}^{\mathrm{r}}$ & This work \\
\hline PDC & $a p h C$ mutant of $\mathrm{P} 1 ; \mathrm{Km}^{\mathrm{r}}$ & This work \\
\hline PDI & aphI mutant of $\mathrm{P} 1 ; \mathrm{Km}^{\mathrm{r}}$ & This work \\
\hline PDJI & aphJI mutant of $\mathrm{P} 1 ; \mathrm{Km}^{\mathrm{r}}$ & This work \\
\hline $\mathrm{PDHJ}$ & aphHJ mutant of $\mathrm{P} 1 ; \mathrm{Km}^{\mathrm{r}}$ & This work \\
\hline \multicolumn{3}{|l|}{ E. coli strains } \\
\hline JM109 & Host strain for DNA manipulation & Toyobo \\
\hline \multicolumn{3}{|l|}{ Plasmids } \\
\hline pUC18 & Cloning vector $; \mathrm{Ap}^{\mathrm{r}}$ & Toyobo \\
\hline pUC19 & Cloning vector; $\mathrm{Ap}^{\mathrm{r}}$ & Toyobo \\
\hline pRW2 & IncP, lacZ promoter-prove vector; $\mathrm{Tc}^{\mathrm{r}}$ & Lodge et al. (1990) \\
\hline pYM50 & $12 \mathrm{~kb}$ EcoRI fragment from TA441 in pUC18 & Arai et al. (1998) \\
\hline pYM70 & $7 \mathrm{~kb}$ HindIII fragment in pUC19 & This work \\
\hline pHAW943 & $a p h C:: l a c Z$ transcriptional fusion in $\mathrm{pRW} 2$ & This work \\
\hline pDT & aphT:: $\mathrm{Km}^{\mathrm{r}}$ in pUC19 & This work \\
\hline $\mathrm{pDC}$ & $a p h C:: \mathrm{Km}^{\mathrm{r}}$ in pUC19 & This work \\
\hline pDI & $a p h I:: \mathrm{Km}^{\mathrm{r}}$ in pUC19 & This work \\
\hline pDJI & aphJI:: $\mathrm{Km}^{\mathrm{r}}$ in pUC19 & This work \\
\hline $\mathrm{pDHJ}$ & $a p h H J:: \mathrm{Km}^{\mathrm{r}}$ in pUC19 & This work \\
\hline pUC18-xylE & $x y l E$ encoding $\mathrm{C} 23 \mathrm{O}$ in $\mathrm{pUC} 18$ & Arai et al. (1999b) \\
\hline pUC18-aphC & $a p h C$ in pUC18 & This work \\
\hline
\end{tabular}


completed, the E. coli cells were removed by filtration, CFE of C. testosteroni strains was added and the decrease in $A_{375}$ was monitored. $\mathrm{NAD}^{+}$was added to $330 \mathrm{mM}$ to the reaction mixture for the HMSD assay. One unit of enzymic activity is defined as the amount of enzyme required to consume $1 \mu \mathrm{mol}$ HMS $\min ^{-1}$. The molar extinction coefficient value for HMS at $375 \mathrm{~nm}$ was $36000 \mathrm{M}^{-1} \mathrm{~cm}^{-1}$.

4-Oxalocrotonate for the enzymatic activity of 4OI and 4OD was produced from catechol as follows. HMS solution was prepared according to the method described above and diluted with $50 \mathrm{mM}$ potassium phosphate buffer $(\mathrm{pH} 7 \cdot 5)$ to an $A_{375}$ of 1.5. HMS in the solution was converted to 4-oxalocrotonate by adding $\mathrm{NAD}^{+}(330 \mathrm{mM})$ and CFE of E. coli JM109 harbouring pUC18-aphC, which was designed to express HMSD (the gene product of $a p h C$ ). For the 4OI assay, CFE of C. testosteroni strains was added to the reaction mixture just after the decrease in $A_{375}$ and the increase in $A_{295}$ had stopped, and the activity was determined by measuring the initial rate of decrease in $A_{295}$ due to the disappearance of the enol form of 4-oxalocrotonate. For the 4OD assay, $\mathrm{MgSO}_{4}(3.3 \mathrm{mM})$ and CFE of C. testosteroni strains were added after the reaction mixture reached an equilibrium state in terms of the levels of the keto and enol forms of 4-oxalocrotonate. The activity was determined by measuring the initial rate of decrease in $A_{235}$ due to the disappearance of the keto form of 4-oxalocrotonate. One unit of activity is defined as the amount of enzyme required to convert $1 \mu \mathrm{mol}$ substrate $\min ^{-1}$. The molar extinction coefficient values for the keto form and the enol form of 4-oxalocrotonate were determined using the equations described by Harayama et al. (1989). pUC18-aphC was constructed as follows. A $2.5 \mathrm{~kb}$ fragment containing the $a p h C$ gene was amplified by PCR from a colony of strain TA441 with oligonucleotides Pri17 (5'-GGCGCGGAATTCACGTCCAGCACGCC- $\left.3^{\prime}\right)$ and Pri20 (5'-GTGTCCTGGATCCTGATCTTCCAGTC-3'), which were designed to introduce EcoRI and BamHI sites, respectively. The amplified fragment was digested with EcoRI and $B a m H I$, and inserted into pUC18 between the EcoRI and BamHI sites in the plasmid.

The enzymic assay of OEH, HOA and ADA was performed according to the methods described by Shingler et al. (1992). The activity of $\beta$-galactosidase, the lac $Z$ gene product, was measured by the protocol described by Miller (1992). The aphC::lacZ fusion plasmid pHAW943 was constructed by insertion of a $1.3 \mathrm{~kb}$ EcoRI-BamHI fragment which contained the $a p h C$ promoter region into pRW 2 between the EcoRI and BamHI sites in the plasmid (Lodge et al., 1990). The fragment was prepared by PCR amplification with oligonucleotides Pri39 (5'-GGCCGGAATTCCACGCCGGGCAGGCG-3') and Pri18 (5'-CCGTAGTGGATCCCACCACGCCCGTC$\left.3^{\prime}\right)$, which were designed to introduce EcoRI and BamHI sites, respectively.

\section{RESULTS AND DISCUSSION}

\section{Cloning, sequencing and characterization of the downstream aph gene cluster}

In Pseudomonas CF600, the genes for phenol degradation (dmpKLMNOPQBCDEFGHI) are transcribed as an extremely large operon (Shingler, 1996). Expression of the operon is regulated by a phenol-sensing transcriptional activator, DmpR, which is encoded divergently from $d m p K$ (Shingler et al., 1993). We have reported the genes for multi-component $\mathrm{PH}$ and $\mathrm{C} 23 \mathrm{O}$ (aphKLMNOPQB), and the gene for a putative phenol- sensing regulator (aphR) in C. testosteroni TA441 (Arai et al., 1998). The aph genes are similar to the corresponding $d m p$ genes in strain CF600 and the order of the genes is conserved between the two strains. The genes for degradation of HMS, which is produced from phenol through the action of $\mathrm{PH}$ and $\mathrm{C} 23 \mathrm{O}$, to TCA cycle intermediates were expected to be located in the vicinity of the $\mathrm{PH}$ and $\mathrm{C} 23 \mathrm{O}$ genes in strain TA441 as is often the case with Gram-negative bacteria. We cloned and sequenced the region downstream of $a p h B$ and identified ten open reading frames (Fig. 1 and Table 2). In the case of strain CF600, the HMSD gene $(d m p C)$ is located just downstream of the $\mathrm{C} 23 \mathrm{O}$ gene $(d m p B)$. However, in the case of strain TA441, the HMSD gene $(a p h C)$ was found about $2.7 \mathrm{~kb}$ downstream of the $\mathrm{C} 23 \mathrm{O}$ gene $(a p h B)$. The genes $a p h B$ and $a p h C$ were found to be separated by two open reading frames of unknown function (orfX, orf Y) and a putative regulatory gene $(a p h T)$. orf $X$ encodes a protein consisting of 296 amino acid residues. The translated sequence of orf $X$ has a typical $\mathrm{N}$-terminal signal sequence for membrane translocation, suggesting that the orf $X$ gene product is located in the periplasm. No protein that has overall similarity with the translated sequence of orf $X$ was found in the protein databases, but a TFASTA search of DNA databases revealed that an OrfX-like protein is encoded in the region downstream of $t d n C$ in Pseudomonas putida UCC2 (GenBank accession no. X59790) and in the region downstream of $c d o E$ in Comamonas sp. JS765 (GenBank accession no. U93090) (Parales et al., 1997). $t d n C$ and $c d o E$ encode 3-methyl catechol 2,3dioxygenase and $\mathrm{C} 23 \mathrm{O}$, respectively, and are similar to $a p h B$. orf $Y$ encodes a relatively hydrophobic protein consisting of 150 amino acid residues. Genes similar to orf $Y$ have been found in some gene clusters encoding meta-pathway enzymes for degradation of aromatic compounds such as $c b z X$ of $P$. putida GJ31, nahX of $P$. putida G7 and cmpX of Sphingomonas sp. HV3 (Grimm \& Harwood, 1999; Mars et al., 1999; Yrjälä et al., 1997). A similar gene was also found in the gene cluster for glycerol metabolism in Citrobacter freundii (Daniel et al., 1995). The role of these orf Y-like genes has not been identified. Our preliminary results showed that an orfXY mutant strain grew poorly on phenol and accumulated yellow HMS in the medium, indicating that the genes are involved in the degradation of HMS (data not shown).

$a p h T$ encodes a protein consisting of 298 amino acid residues. Analysis of the translated sequence of $a p h T$ has shown that this gene product belongs to the LysR family of transcriptional regulators. AphT shows high similarity to CdoR from Comamonas sp. JS765 (Parales et al., 1997). cdoR is located adjacent to cdoTE, in the opposite orientation, and the latter correspond to $a p h Q B$ of strain TA441 encoding a ferredoxin-like protein and $\mathrm{C} 23 \mathrm{O}$. AphT is also similar to CatR-type and ClcR-type regulators, which regulate the genes for the ortho-cleavage pathway for degradation of catechol and 3-chlorocatechol, respectively (Table 2 ). The compounds recognized as sensing signals by CatR and ClcR 
Table 2. Gene products of the downstream aph gene cluster of strain TA441 and homology with other proteins

\begin{tabular}{|c|c|c|c|}
\hline Gene & $\begin{array}{l}\text { No. amino } \\
\text { acids }\end{array}$ & Gene product & Identity with other gene products $(\%)^{*}$ \\
\hline $\operatorname{orf} X$ & 296 & Unknown & \\
\hline orf $Y$ & 150 & Unknown & CbzX (69), NahX (58), CmpX (45), OrfY (36) \\
\hline aphT & 298 & LysR-type regulator & $\begin{array}{l}\text { CdoR (68), TfdR (38), CatR (36), ClcR (37), TcbR } \\
\text { (33) }\end{array}$ \\
\hline$a p h C$ & 484 & HMSD & DmpC (73), XylG (68) \\
\hline$a p h E$ & 260 & $\mathrm{OEH}$ & $\begin{array}{l}\text { DmpE (70), XylJ (68), TodG (45), BphE (74), MhpD } \\
(44)\end{array}$ \\
\hline$a p h F$ & 307 & ADA & $\begin{array}{l}\text { DmpF (58), XylQ (58), TodI (57), BphG (88), MhpF } \\
(58)\end{array}$ \\
\hline$a p h G$ & 345 & $\mathrm{HOA}$ & $\begin{array}{l}\text { DmpG (56), XylK (56), TodH (56), BphF (85), MhpE } \\
(58)\end{array}$ \\
\hline$a p h H$ & 263 & 4OD & DmpH (62), XylI (59) \\
\hline$a p h J$ & 326 & Unknown & $\begin{array}{l}\text { Orf4 (36), Orf5 (35), tcb-Orf3 (39) clc-Orf3 (41), Orf7 } \\
\text { (36) }\end{array}$ \\
\hline$a p h I$ & 63 & $4 \mathrm{OI}$ & DmpI (43), XylH (44) \\
\hline
\end{tabular}

*Percentage identity at the amino acid level is given: CbzX is from P. putida GJ31 (Mars et al., 1999); NahX, P. putida G7 (Grimm \& Harwood, 1999); CmpX, Sphingomonas sp. HV3 (Yrjälä et al., 1997); OrfY, glycerol metabolism of Citrobacter freundii (Daniel et al., 1995); CdoR, Comamonas sp. JS765 (Parales et al., 1997); TfdR, Alcaligenes eutrophus JMP134 (Streber et al., 1987); CatR, P. putida (Rothmel et al., 1990); ClcR, P. putida (Coco et al., 1993); TcbR, Pseudomonas sp. P51 (van der Meer et al., 1991b); Dmp, Pseudomonas sp. CF600 (Shingler et al., 1992); Xyl, TOL plasmid pWW0 (Harayama \& Rekik, 1990); Tod, P. putida F1 (Lau et al., 1994); Bph, Burkholderia sp. LB400 (Erickson \& Mondello, 1992); Mhp, C. testosteroni TA441 (Arai et al., 1999b); Orf4 and Orf5, 3-(3hydroxyphenyl)propionate degradation of C. testosteroni TA441 (Arai et al., 1999b); tcb-Orf3, Pseudomonas sp. P51 (van der Meer et al., 1991a); clc-Orf3, catabolic plasmid pAC27 (Franz \& Chakrabarty, 1987); Orf7, poly(3-hydroxybutyrate-co-4-hydroxybutyrate) synthesis of A. eutrophus H16 (Valentin et al., 1995).

are cis,cis-muconate and 2-chloro-cis, cis-muconate, the ortho-cleavage compounds produced from catechol and 3-chlorocatechol, respectively (McFall et al., 1997; Parsek et al., 1992). Phylogenetic analysis of LysRfamily regulators revealed that AphT is grouped with the ClcR-type regulators (Fig. 3).

The HMSD gene $(a p h C)$ was found to be followed by the genes aphEFG encoding OEH, ADA, and HOA, respectively. These three enzymes catalyse the final three steps of the meta-pathway and these reactions are common to other meta-degradation pathways for various aromatic compounds. The $\mathrm{N}$-terminal sequence of the $a p h G$ gene product is highly similar (26 of 28 amino acids identical) to that of a protein (TIP4), which is induced by testosterone in C. testosteroni (ATCC 11996) (Möbus et al., 1997). However, aphG mutants of strains TA441 and of the adapted strain P1 were found to be capable of growth with testosterone as a carbon source (data not shown). An $a p h G$ mutant of strain P1 was also able to grow on phenol, indicating that the $a p h G$ gene is not necessary for utilization of phenol (data not shown). Strain TA441 has another set of genes (mhpDFE) encoding the enzymes for the final three steps of the meta-pathway corresponding to aphEFG (Arai et al., $1999 \mathrm{~b})$. The $m b p D F E$ genes are involved in degradation of 3-(3-hydroxyphenyl)propionate (3HPP). Probably, $m b p E$ or another unidentified isofunctional gene, which might encode TIP4, complements the mutation in aphG.

The genes for the 4-oxalocrotonate branch enzymes 4OD $(a p h H)$ and 4OI $(a p h I)$ followed $a p h G$. An open reading frame of unknown function $(a p h J)$ was located between $a p h H$ and $a p h I$. aphJ encodes a protein consisting of 326 amino acid residues. The translated sequence of $a p h J$ has a typical N-terminal signal sequence for membrane translocation, suggesting that the $a p h J$ gene product is located in the periplasm. Strain TA441 has two other aphJ-like open reading frames (orf4 and orf5) in the $m b p$ gene clusters for degradation of 3HPP (Arai et al., 1999b). orf4 encodes a product with an N-terminal signal sequence, whereas orf5 does not encode a signal sequence. orf 4 and orf5 are not necessary for utilization of 3HPP and their roles are still unclear (Arai et al., 1999b). An aphJ-like gene has been found also in the gene cluster for the chlorocatechol orthodegradation pathway in Pseudomonas sp. P51 (ORF3 of the $t c b$ gene cluster) (van der Meer et al., 1991a), and in the catabolic plasmid pAC27 (ORF3 of the clc gene cluster) (Frantz \& Chakrabarty, 1987), and in the gene cluster for biosynthesis of poly (3-hydroxybutyrate-co-4hydroxybutyrate) in Alcaligenes eutrophus H16 (ORF7) 


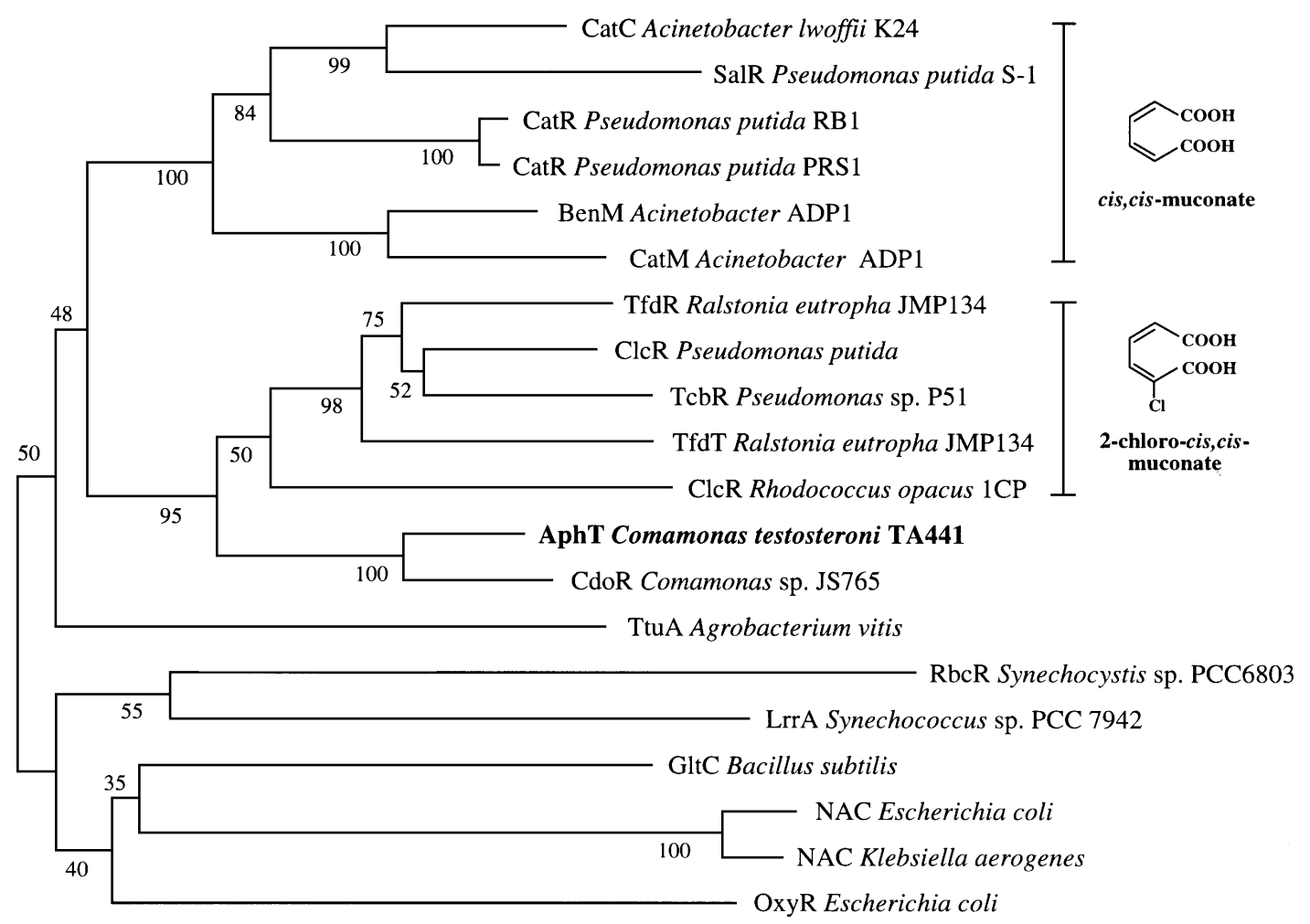

Fig. 3. Phylogenetic tree for AphT and the LysR family of transcriptional regulators. Multiple sequence alignment was done using CLUSTAL W. Tree topology and evolutionary distance estimations were done by the neighbour-joining method (PHYLIP 3.5). The numbers indicated at the nodes are bootstrap values calculated from 100 replications using the SEQBOOT, PROTDIST, NEIGHBOR and CONSENSE programs of the PHYLIP 3.5 program package. cis,cis-Muconate and 2-chloro-cis,cismuconate are the effectors for the CatR-type and the ClcR-type regulators, respectively.

Table 3. Activity of the meta-pathway enzymes

Activity was measured in CFE after the C. testosteroni strains were grown in C medium supplemented with $5 \mathrm{mM}$ phenol, pHB or succinate for 16-18 h. Values are means from at least three independent experiments. ND, Not determined.

\begin{tabular}{|c|c|c|c|c|c|c|c|c|}
\hline \multirow[t]{2}{*}{ Strain } & \multirow[t]{2}{*}{ Carbon source } & \multicolumn{7}{|c|}{ Enzyme activity } \\
\hline & & $\begin{array}{c}\text { HMSH } \\
\left(\mathrm{mU} \mathrm{mg}^{-1}\right)\end{array}$ & $\begin{array}{l}\text { HMSD } \\
\left(\mathrm{mU} \mathrm{mg}^{-1}\right)\end{array}$ & $\begin{array}{c}\text { 4OI } \\
\left(\mathrm{U} \mathrm{mg}^{-1}\right)\end{array}$ & $\begin{array}{c}\text { 4OD } \\
\left(\mathrm{U} \mathrm{mg}^{-1}\right)\end{array}$ & $\begin{array}{c}\mathrm{OEH} \\
\left(\mathrm{U} \mathrm{mg}^{-1}\right)\end{array}$ & $\begin{array}{c}\text { HOA } \\
\left(\mathrm{mU} \mathrm{mg}^{-1}\right)\end{array}$ & $\begin{array}{c}\text { ADA } \\
\left(\mathrm{mU} \mathrm{mg}^{-1}\right)\end{array}$ \\
\hline P1 & Phenol & 4 & 138 & $9 \cdot 2$ & $0 \cdot 89$ & $10 \cdot 7$ & 79 & 80 \\
\hline P1 & $\mathrm{pHB}$ & ND & 3 & $0 \cdot 7$ & $0 \cdot 01$ & $2 \cdot 6$ & 113 & 0 \\
\hline P1 & Succinate & ND & 3 & $0 \cdot 6$ & $0 \cdot 00$ & $0 \cdot 7$ & 61 & 0 \\
\hline PDT & Phenol & 6 & 55 & $7 \cdot 1$ & 0.53 & $7 \cdot 0$ & 74 & 40 \\
\hline PDT & $\mathrm{pHB}$ & ND & 16 & $3 \cdot 5$ & $0 \cdot 19$ & $4 \cdot 3$ & 122 & 5 \\
\hline PDT & Succinate & ND & 8 & $1 \cdot 0$ & $0 \cdot 10$ & $2 \cdot 0$ & 51 & 3 \\
\hline
\end{tabular}

(Valentin et al., 1995). ORF3 of the $t c b$ gene cluster and ORF7 in A. eutrophus H16 encode putative proteins with N-terminal signal sequences, whereas ORF3 in the clc gene cluster does not encode a signal sequence. Similar genes have also been found in the gene clusters for metabolism of tartrate and urea (McMillan et al., 1998; Salomone et al., 1996). However, the roles of these genes have not yet been identified.
The gene for HMSH corresponding to $d m p D$ of strain CF600 was not found in the $a p h$ gene cluster of strain TA441. Enzymic conversion of HMS by cells of this strain adapted to growth on phenol was completely dependent on $\mathrm{NAD}^{+}$, indicating that strain TA441 does not have the $\mathrm{NAD}^{+}$-independent HMSH and has only the $\mathrm{NAD}^{+}$-dependent HMSD (Table 3). The hydrolytic branch involving the step catalysed by HMSH is 




Fig. 4. Growth of $C$. testosteroni strains on phenol. The strains were grown in $100 \mathrm{ml} \mathrm{C}$ medium supplemented with $5 \mathrm{mM}$ phenol. ๑, P1; $\Delta$, PDT; $\mathbf{\square}$, PDC; $\nabla$, PDHJ; $\diamond$, PDJI; $\square$, PDI.

required for degradation of 2- and/or 3-methylated phenols (Shingler, 1996). Strain P1 could not utilize methylphenols, confirming the deficiency in $\mathrm{HMSH}$ (data not shown). The lack of the hydrolytic branch was also confirmed by results indicating that 4-oxalocrotonate branch mutants, strain PDC $\left(a p h C^{-}\right)$and strain PDHJ $\left(a p h H^{-}, a p h J^{-}\right)$, were not able to grow through utilization of phenol (Fig. 4). The 4OI mutant strains PDI $\left(a p h I^{-}\right)$and PDJI $\left(a p h J^{-}, a p h I^{-}\right)$were able to grow on phenol although growth was delayed compared to that of the parent strain P1 (Fig. 4). Our findings demonstrate that $a p h J$ is not necessary for utilization of phenol; strains PDI and PDJI showed similar growth profiles (Fig. 4) and strain PDHJ was able to grow on phenol when transformed with the aphH gene (data not shown). 4OI encoded by aphI catalyses the isomerization of the enol form of 4-oxalocrotonate to the keto form. The phenol-grown cells of strain PDI did not display 4OI enzymic activity (data not shown). The growth of strains PDI and PDJI was attributable to the spontaneous isomerization of 4-oxalocrotonate. This result differs from the cases of strain CF600 and P. putida $\mathrm{U}$, in which the 4OI gene is essential for growth on phenol (Powlowski \& Shingler, 1994; Wigmore et al., 1974).

\section{Regulation of the meta-pathway enzymes}

Strain TA441 could grow on phenol when the recombinant aphKLMNOPQB genes were expressed, driven by a tac promoter, indicating that transcription of the downstream meta-pathway genes is independent of the upstream $a p h K$ operon. (Arai et al., 1998). In the case of strain CF600, the genes for all the enzymes required for degradation of phenol are transcribed as an operon (Shingler, 1996). However, strain TA441 must have an additional regulatory system specific for the downstream $a p h$ gene cluster. The arrangement of the oppositely oriented $a p h T$ gene upstream of the $a p h C$ gene suggests that AphT may be concerned with regulation of transcription directed by the $a p h C$ promoter (Fig. 1). For investigation of the role of $a p h T$, we constructed the $a p h T$ mutant strain PDT from strain P1, and compared the levels of activity of the meta-pathway enzymes in strains P1 and PDT (Table 3).

Strain PDT was able to grow on phenol, indicating that $a p h T$ is not necessary for degradation of phenol (Fig. 4). In strain P1, the activity of each of the meta-pathway enzymes except HOA was induced when phenol was being used as a carbon source, indicating that the expression of these enzymes is under the control of a regulatory system responsive to phenol or its metabolites. The HOA activity was expressed even when the strain was grown on succinate, and the activity was highest when $\mathrm{pHB}$ was being used as a carbon source. The HOA activity in cells grown on $\mathrm{pHB}$ or succinate was probably attributable to the expression of isofunctional enzymes such as MhpE and TIP4, derived from genes other than $a p h G$. The levels of HMSD, 4OI, $4 \mathrm{OD}, \mathrm{OEH}$ and ADA activity in strain PDT were lower than those in strain P1 when phenol was added, suggesting that AphT may be involved in the induction of these enzymes. However, the role of the aphT gene in the phenol-grown cells was not so important because induction of the enzymes by phenol was still operative and growth on phenol was not affected by mutation in $a p h T$. The levels of HMSD, 4OI, 4OD, OEH and ADA activity in strain PDT grown in the presence of $\mathrm{pHB}$ or succinate were higher than those in strain P1. This was probably because of read-through from the $\mathrm{Km}^{\mathrm{r}}$ gene that was inserted in the aphT gene.

\section{Dual regulation of the aphC promoter by AphR and AphT}

The transcriptional activity of the $a p h C$ promoter was assessed by monitoring the expression of $\beta$-galactosidase from the lacZ-fusion plasmid pHAW943 (Fig. 5). Interestingly, strains TA441 and P1 showed quite different induction patterns. The $a p h C$ promoter activity was significantly increased in strain TA441 upon incubation with HMS (Fig. 5a). The promoter activity in strain P1 was lower than that in strain TA441 for some unknown reason. The induction by HMS was not observed in the aphT-deficient strains TDT and PDT, indicating that the HMS-mediated activation of the $a p h C$ promoter was under the control of AphT. The activity in strain PR921, an $a p h R$ derivative of strain P1 (Arai et al., 1998), was comparable to that in strain P1, indicating that AphR is not involved in the activation by HMS. The compound recognized as a sensing signal by AphT is probably HMS, because the activity in strain PDC, in which HMS was not further metabolized, was also comparable to that in strain P1. 


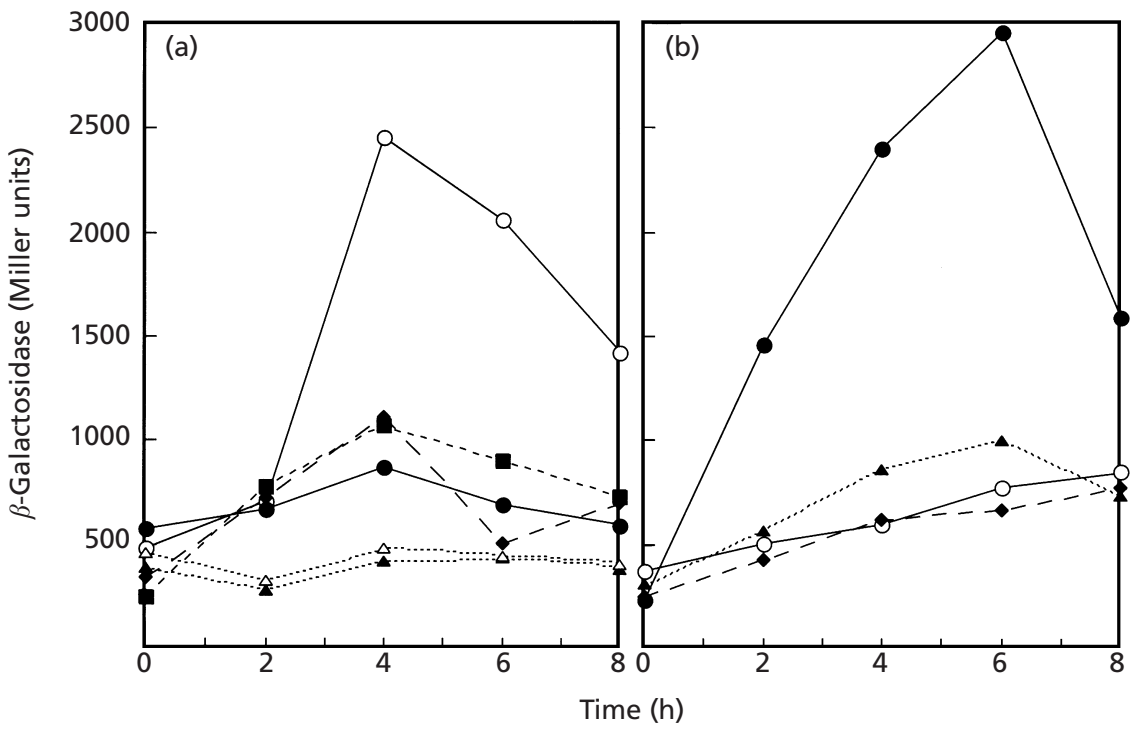

Fig. 5. Transcriptional activity of the aphC promoter in C. testosteroni strains. The strains were transformed with pHAW943 carrying the transcriptional fusion construct aphC::lacZ. Cultures of the strains grown overnight in $\mathrm{C}$ medium with $\mathrm{pHB}$ as a carbon source were diluted 10 -fold with $C$ medium containing $0.4 \mathrm{mM}$ HMS (a) or $5 \mathrm{mM}$ phenol (b). The changes in the levels of activity of $\beta$-galactosidase, the lac $Z$ gene product, were monitored for $8 \mathrm{~h}$. The data are representative of at least two experiments. $\bigcirc, \mathrm{TA} 441 ; 0, \mathrm{P} 1 ; \triangle, \mathrm{TDT} ; \boldsymbol{\Delta}$, PDT; $\mathbf{\square}$ PDC; $\diamond$ PR921.
The $a p h C$ promoter activity in strain $\mathrm{P} 1$ was significantly induced upon incubation with phenol (Fig. 5b). The induction was also observed in strain PDT although the level of expression was significantly lower than in strain P1. Induction of the downstream meta-pathway genes by phenol in strain PDT was confirmed through assay of the levels of enzyme activity (Table 3). The induction by phenol was poor in strains PR921 or TA441, in which $a p h R$ was disrupted or expression of $a p h R$ was repressed, respectively. These results indicated that the phenol-induced activation of the $a p h C$ promoter was mediated by AphR. The high activity in strain P1 was probably a synergistic effect of AphR and AphT, considering that HMS is produced during the degradation of phenol.

The results of the present study indicate that the $a p h C$ promoter is subject to dual regulation by AphR and AphT. Phenol-sensing regulation by AphR is dominant in the adapted strain P1. On the contrary, in strain TA441, HMS-sensing regulation by AphT occurs exclusively because the expression of AphR is repressed by AphS. Interestingly, the $a p h C$ promoter was not silenced by AphS as in the case of the upstream $a p h R$ promoter, suggesting that strain TA441 could degrade HMS not derived from phenol.

The distance between $a p h G$ and $a p h H$ is a relatively long stretch (697 bp), but no transcriptional activity was detected in the aphG-aphH intervening region (data not shown). Because the downstream meta-pathway enzymes except HOA were found to be similarly regulated (Table 3), the aphCEFGHJI genes might be transcribed as an operon. Our preliminary data showed that AphT binds to the $a p h G-a p h H$ intervening region. 4OI and 4OD, encoded by $a p h I$ and $a p h H$, catalyse the isomerization and decarboxylation of 4-oxalocrotonate, respectively (Fig. 2). The structure of the enol form of 4oxalocrotonate, the substrate of $4 \mathrm{OI}$, is very similar to that of 2-chloro-cis,cis-muconate (Fig. 3). Considering that AphT is phylogenetically close to regulators known to recognize 2-chloro-cis,cis-muconate, AphT might recognize 4-oxalocrotonate. There is a possibility that AphT is involved in 4-oxalocrotonate-sensing fine regulation of the aphHJI subcluster in addition to playing a role in HMS-sensing activation of the $a p h C$ promoter.

\section{ACKNOWLEDGEMENTS}

This work was partially supported by Special Coordination Funds for Promoting Science and Technology from the Science and Technology Agency of the Japanese Government and by a grant for the Eco Molecular Sciences Research Program from RIKEN.

\section{REFERENCES}

Arai, H., Akahira, S., Ohishi, T., Maeda, M. \& Kudo, T. (1998). Adaptation of Comamonas testosteroni TA441 to utilize phenol: organization and regulation of the genes involved in phenol degradation. Microbiology 144, 2895-2903.

Arai, H., Akahira, S., Ohishi, T. \& Kudo, T. (1999a). Adaptation of Comamonas testosteroni TA441 to utilization of phenol by spontaneous mutation of the gene for a trans-acting factor. Mol Microbiol 33, 1132-1140.

Arai, H., Yamamoto, T., Ohishi, T., Shimizu, T., Nakata, T. \& Kudo, T. (1999b). Genetic organization and characteristics of the 3(3-hydroxyphenyl)propionic acid degradation pathway from Comamonas testosteroni TA441. Microbiology 145, 2813-2820.

Bradford, M. M. (1976). A rapid and sensitive method for the quantitation of microgram quantities of protein utilizing the principle of protein-dye binding. Anal Biochem 72, 248-254.

Coco, W. M., Rothmel, R. K., Henikoff, S. \& Chakrabarty, A. M. (1993). Nucleotide sequence and initial functional characterization of the $c l c R$ gene encoding a LysR family activator of the clcABD chlorocatechol operon in Pseudomonas putida. J Bacteriol 175, 417-427.

Daniel, R., Stuertz, K. \& Gottschalk, G. (1995). Biochemical and molecular characterization of the oxidative branch of glycerol utilization by Citrobacter freundii. J Bacteriol 177, 4392-4401. 
Erickson, B. D. \& Mondello, F. J. (1992). Nucleotide sequencing and transcriptional mapping of genes encoding biphenyl dioxygenase, a multicomponent PCB-degrading enzyme in Pseudomonas strain LB400. J Bacteriol 174, 2903-2912.

Frantz, B. \& Chakrabarty, A. M. (1987). Organization and nucleotide sequence determination of a gene cluster involved in 3chlorocatechol degradation. Proc Natl Acad Sci USA 84, 4460-4464.

Grimm, A. C. \& Harwood, C. S. (1999). NahY, a catabolic plasmidencoding receptor required for chemotaxis of Pseudomonas putida to the aromatic hydrocarbon naphthalene. J Bacteriol 181, 3310-3316.

Harayama, S. \& Rekik, M. (1990). The meta cleavage operon of TOL degradative plasmid $\mathrm{pWW0}$ comprises 13 genes. Mol Gen Genet 221, 113-120.

Harayama, S., Rekik, M., Ngai, K.-L. \& Ornston, L. N. (1989). Physically associated enzymes produce and metabolize 2hydroxypent-2,4-dienoate, a chemically unstable intermediate formed in catechol metabolism via meta cleavage in Pseudomonas putida. J Bacteriol 171, 6251-6258.

Lau, P. C., Bergeron, H., Labbe, D., Wang, Y., Brousseau, R. \& Gibson, D. T. (1994). Sequence and expression of the todGIH genes involved in the last three steps of toluene degradation by Pseudomonas putida F1. Gene 146, 7-13.

Lodge, J., Williams, R., Bell, A., Chan, B. \& Busby, S. (1990). Comparison of promoter activities in Escherichia coli and Pseudomonas aeruginosa: use of a new broad-host-range promoter-probe plasmid. FEMS Microbiol Lett 67, 221-226.

McFall, S. M., Parsek, M. R. \& Chakrabarty, A. M. (1997). 2Chloromuconate and ClcR-mediated activation of the $c l c A B C$ operon: in vitro transcriptional and DNase I footprint analyses. $J$ Bacteriol 179, 3655-3663.

McMillan, D. J., Mau, M. \& Walker, M. J. (1998). Characterisation of the urease gene cluster in Bordetella bronchiseptica. Gene 208, 243-251.

Mars, A. E., Kingma, J., Kaschabek, S. R., Reineke, W. \& Janssen, D. B. (1999). Conversion of 3-chlorocatechol by various catechol 2,3-dioxygenases and sequence analysis of the chlorocatechol dioxygenase region of Pseudomonas putida GJ31. J Bacteriol 181, 1309-1318.

van der Meer, J. R., Eggen, R. I., Zehnder, A. J. \& de Vos, W. M. (1991a). Sequence analysis of the Pseudomonas sp. strain P51 tcb gene cluster, which encodes metabolism of chlorinated catechols: evidence for specialization of catechol 1,2-dioxygenases for chlorinated substrates. J Bacteriol 173, 2425-2434.

van der Meer, J. R., Frijters, A. C., Leveau, J. H., Eggen, R. I., Zehnder, A. J. \& de Vos, W. M. (1991b). Characterization of the Pseudomonas sp. strain P51 gene $t c b R$, a LysR-type transcriptional activator of the $t c b C D E F$ chlorocatechol oxidative operon, and analysis of the regulatory region. J Bacteriol 173, 3700-3708.

Miller, J. H. (1992). A Short Course in Bacterial Genetics: a Laboratory Manual and Handbook for Escherichia coli and Related Bacteria. Cold Spring Harbor, NY: Cold Spring Harbor Laboratory.

Möbus, E., Jahn, M., Schmid, R., Jahn, D. \& Maser, E. (1997). Testosterone-regulated expression of enzymes involved in steroid and aromatic hydrocarbon catabolism in Comamonas testosteroni. J Bacteriol 179, 5951-5955.
Parales, R. E., Ontl, T. A. \& Gibson, D. T. (1997). Cloning and sequence analysis of a catechol 2,3-dioxygenase gene from the nitrobenzene-degrading strain Comamonas sp. JS765. J Ind Microbiol Biotechnol 19, 385-391.

Parsek, M. E., Shinabarger, D. L., Rothmel, R. K. \& Chakrabarty, A. M. (1992). Roles of CatR and cis,cis-muconate in activation of the cat $B C$ operon, which is involved in benzoate degradation in Pseudomonas putida. J Bacteriol 174, 7798-7806.

Powlowski, J. \& Shingler, V. (1994). Genetics and biochemistry of phenol degradation by Pseudomonas sp. CF600. Biodegradation 5, 219-236.

Rothmel, R. K., Aldrich, T. L., Houghton, J. E., Coco, W. M., Ornston, L. N. \& Chakrabarty, A. M. (1990). Nucleotide sequencing and characterization of Pseudomonas putida catR: a positive regulator of the $c a t B C$ operon is a member of the lysR family. J Bacteriol 172, 922-931.

Salomone, J.-Y., Crouzet, P., De Ruffray, P. \& Otten, L. (1996). Characterization and distribution of tartrate utilization genes in the grapevine pathogen Agrobacterium vitis. Mol Plant-Microbe Interact 9, 401-408.

Sambrook, J., Fritsch, E. F. \& Maniatis, T. (1989). Molecular Cloning: a Laboratory Manual, 2nd edn. Cold Spring Harbor, NY : Cold Spring Harbor Laboratory.

Shingler, V. (1996). Metabolic and regulatory check points in phenol degradation by Pseudomonas sp. CF600. In Molecular Biology of Pseudomonas, pp. 153-154. Edited by T. Nakazawa, K. Furukawa, D. Haas \& S. Silver. Washington, DC: American Society for Microbiology.

Shingler, V., Powlowski, J. \& Marklund, U. (1992). Nucleotide sequence and functional analysis of the complete phenol/3,4dimethylphenol catabolic pathway of Pseudomonas sp. strain CF600. J Bacteriol 174, 711-724.

Shingler, V., Bartilson, M. \& Moore, T. (1993). Cloning and nucleotide sequence of the gene encoding the positive regulator (DmpR) of the phenol catabolic pathway encoded by pVI150 and identification of DmpR as a member of the NtrC family of transcriptional activators. J Bacteriol 175, 1596-1604.

Simon, R. (1984). High frequency mobilization of gram-negative bacterial replicons by the in vitro constructed Tn5-Mob transposon. Mol Gen Genet 196, 413-420.

Streber, W. R., Timmis, K. N. \& Zenk, M. H. (1987). Analysis, cloning, and high-level expression of 2,4-dichlorophenoxyacetate monooxygenase gene $t f d A$ of Alcaligenes eutrophus JMP134. J Bacteriol 169, 2950-2955.

Valentin, H. E., Zwingmann, G., Schonebaum, A. \& Steinbüchel, A. (1995). Metabolic pathway for biosynthesis of poly(3hydroxybutyrate-co-4-hydroxybutyrate) from 4-hydroxybutyrate by Alcaligenes eutrophus. Eur J Biochem 227, 43-60.

Wigmore, H. J., Bayly, R. C. \& Berardino, D. (1974). Pseudomonas putida mutants defective in metabolism of the products of metafission of catechol and its methyl analogues. J Bacteriol 120, 31-37.

Yrjälä, K., Paulin, L. \& Romantschuk, M. (1997). Novel organization of catechol meta-pathway genes in Sphingomonas sp. HV3 pSKY4 plasmid. FEMS Microbiol Lett 154, 403-408.

Received 11 January 2000; revised 27 March 2000; accepted 4 April 2000. 